\title{
Capital in the Twenty-First Century: A Critique of Thomas Piketty's Political Economy
}

\author{
Michael Potter
}

Capital in the Twenty-First Century, by French economist Thomas Piketty, is a book that has come out at the right time for public intellectuals, who are taken with its story of high and growing inequality, the damage done, and the need for punitive taxes to remedy this damage. Paul Krugman (2014) declares: 'Piketty has written a truly superb book ... This is a book that will change both the way we think about society and the way we do economics.' While there have been many other books and articles written recently about inequality (for example, Stiglitz 2013 and Wilkinson and Pickett 2009) Piketty's book stands out in terms of the focus it has received and the sales made (See VanderMey 2014 for a detailed discussion of the success of the book).

The title Capital in the Twenty-First Century (henceforth Capital) derives from the book's focus on tracking movements in capital (or what non-economists would call wealth) and the impact of capital on worsening inequality. The title of Piketty's book obviously echoes Das Kapital. Both books make bold, sweeping predictions about the future. And Piketty's book has obvious Marxist leanings by assuming that the existence of rich and poor in the long run is mostly due to the existence of profits (for the rich) and wages (for the poor). Perhaps Piketty thinks his book will be as influential as Marx's. But he is surely hoping it will stand the test of time better than Marx's theories.

This paper examines the now extensive literature on Capital to scrutinise 1. Piketty's data; 2. his explanation of the data; 3. the significance he attributes to this data; and 4. his remedy for the supposed problems.

\section{Overview of the data and arguments}

The main measure that Capital uses for inequality is the share of income (or wealth) that goes to the top portion (10, 1 or 0.1 per cent). Capital argues that this measure of inequality has significantly increased in recent decades, as illustrated in the figure below based on Figure 9.2 in Capital. 


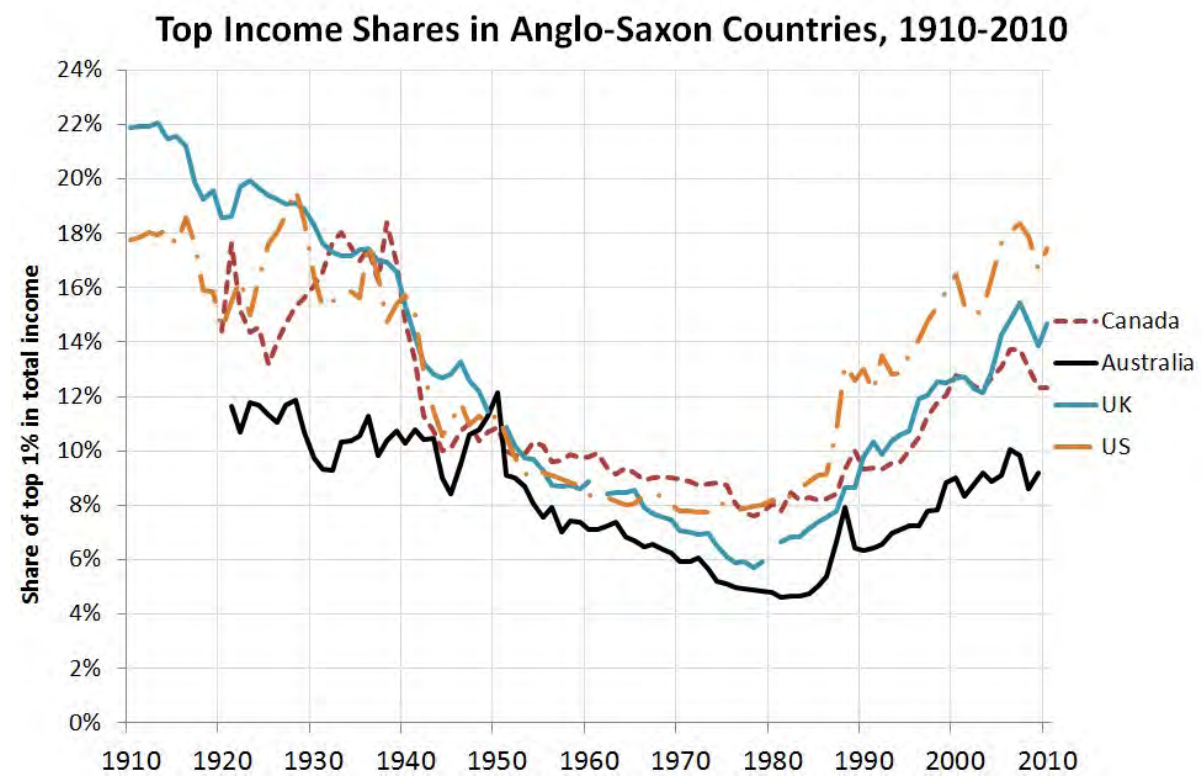

Figure 1: Top income shares in Anglo-Saxon countries, 1910-2010

Source: Author's adaptation of Figure 9.2, Capital in the Twenty-First Century, Thomas Piketty.

While Capital measures inequality through the shares of incomes going to the rich, there are many other measures, including the Gini coefficient. Piketty discards these indexes as misleading because they try to 'summarise a multidimensional reality with a unidimensional index' (p. 266). ${ }^{1}$ However, Piketty is not consistent - Capital also sometimes summarises inequality with a single figure. In addition, Capital's use of income shares means that some of Piketty's arguments are difficult to reconcile with other studies (discussed below) that produce very different results.

Income in the economy can come from wages, the returns on wealth ('capital') or from government transfers (e.g. pensions). Piketty focuses on income from wages and wealth and entirely leaves out the government - an omission explored further below.

Capital presents data showing that wealth inequality in several countries fell between about 1900 and 1970, and has increased slightly since then (Chapter 10), based on measuring capital as a share of the income earned in the economy. Capital uses the terms capital and wealth interchangeably to mean the value of

1 The page numbers are from the Kindle edition of Capital and so may not correspond exactly to the hard
copy. 
all assets, including land, housing, shares, art, bank accounts, plant, equipment and intellectual property. This terminology is somewhat misleading: most people would use 'wealth' to cover assets such as land and art, but not 'capital'.

Piketty argues that the decline in income and wealth inequality from 1910 to about 1970/80 were caused by factors including the Great Depression, the two world wars, increased taxes and various social policies. Piketty forecasts significant increases in the value of wealth, and the inequality of wealth and income in this century, on the basis of his forecasts for low economic growth and high returns to wealth during the 21 st century. He argues this is a major problem and in response argues for increased taxes on wealth, the income to wealth, and inheritances of wealth. He is, however, less supportive of other solutions to inequality, including inflation, capital controls, immigration, and protectionism; and he is only lukewarm about education as a solution.

\section{A critical examination of the inequality data}

Piketty's inequality analysis is largely based on data from tax returns. He argues that this enables better analysis of top incomes over time, because surveys (the other option for collecting data on inequality) can't measure the highest incomes correctly (p. 257, p. 329) and cover much shorter periods than the tax data. However, using tax return data has large problems. It a) leaves out income support and government transfers; b) incorrectly measures capital gains; c) omits non-taxable income entirely; and d) is sensitive to changes in the definitions of taxable income.

These are major problems, calling into question the basis of his whole book. I deal with these issues in turn.

\section{Omission of income support and government transfers}

The data from tax returns used in Capital is based on market incomes and leaves out the effect of income support and welfare programs such as health and education. Capital does spend some time analysing the growth in the welfare state (in Part 4), but it completely leaves out the impact of this in the data on inequality in the first three parts of the book and therefore omits the main force that has offset inequality in market incomes.

As an illustration of the impact of this omission, when welfare income is included, the (disposable) income of the bottom 90 per cent in the US rose nearly \$12,000 between 1979 and 2012, whereas Piketty's data has this income dropping by $\$ 3,000$ (Winship 2014). Similar arguments are in Burkhauser and 
Larrimore (2014) and Milanovic (2013). Interestingly, Burkhauser and Larrimore suggest that the growth of the welfare state may have increased the inequality of incomes excluding welfare, presumably because welfare reduces the incentives to work for those on low incomes. If this is true, then this further emphasises the problems caused by leaving out welfare payments from analysis of inequality.

Similarly, Piketty also leaves out most of the total wealth of poor and middleclass households; namely, their claims to current and future income support and health benefits (Kotlikoff 2014, and Mount 2014). ${ }^{2}$ Suppose I have a private pension that pays me $\$ 20,000$ and you have a public pension that pays the same amount - the first asset that generates the private pension (more likely to be held by the wealthy) is counted in Piketty's wealth data but the second (more likely to be held by the less wealthy) isn't (Worstall 2014). For Australia, the age pension has been growing in real terms for many years. Along with increases in life expectancy, partly offset by increases in the pension age, this means that the value of the 'age pension asset' has also grown, and this would predominantly be an asset for the least well off in society. ${ }^{3}$

This means that Piketty's conclusions on both income and wealth inequality are misleading and inaccurate.

\section{Incorrect measurement of capital gains}

Piketty's tax return data include capital gains as income in the year in which assets are sold. But a better measure of income includes capital gains when they accrue rather than when they are realised. Armour, Burkhauser and Larrimore (2013: 25) use accrued capital gains rather than realised taxable gains and find: 'The top quintile of the income distribution had the slowest income growth from 1989 through 2007, while the bottom quintile had the fastest.'

\section{Omission of non-taxable income}

The data used in Capital also do not include non-taxable income. Piketty argues the exemptions from capital gains taxes benefit the wealthy, so that this omission means inequality is understated (p. 282). However, he neglects to analyse the exemption fully - there are exclusions that benefit a much wider range of the population, including exemptions for the gains on sale of the home

2 The figures on net wealth also fail to subtract a substantial liability for the rich - their future tax payments. Inclusion of this debt would further reduce wealth inequality.

3 In Australia in 1970 the age pension for a single person stood at \$7,283 per annum in 2012 consumer prices. In 2012 the actual age pension for a single person was $\$ 19,278$, a real increase of 171 per cent. 
and the value of health insurance (Winship 2014) and the imputed rent on owner-occupied houses (Cross 2014). In Australia, the inclusion of imputed rent reduces measured income inequality. ${ }^{4}$

\section{Definition of taxable income}

Some of the apparent changes in the distribution of income could be an artefact of amendments to the definitions of taxable income. One-third of the measured increase in US income for the top 1 per cent from 1985 to 2012 could be due to a reclassification of income for tax purposes, rather than a true change in inequality (Burkhauser and Larrimore 2014). For Australia, an apparent spike in top incomes between 1986 and 1989 appears to be due to a change in tax rules and the measured growth in inequality since 1989 seems to be due to the introduction of the capital gains tax (Burkhauser and Larrimore 2014).

\section{Other concerns}

There are other concerns with the data in Capital, including:

- Giles and Giugliano (2014) argue that when they correct for 'errors' in Piketty's data they find that 'the European results do not show any tendency towards rising wealth inequality after 1970'. Piketty has replied, addressing these criticisms in some detail (Piketty 2014b).

- Historically, tax returns (the source of Piketty's data) were only filed by a small percentage of the population (Milanovic 2013).

\section{Different conclusions reached by others}

Other commentators have examined inequality data and found quite different conclusions.

Globally, income inequality (measured by the Gini coefficient) fell slightly from 1988 to 2008, including when Piketty's concerns about correct measurement of top incomes are addressed (Lakner and Milanovic 2014). So the apparent increase in inequality is occurring within countries rather than across the globe and could be seen as an artefact of where country boundaries are drawn.

Specifically for the United States:

4 See: http://www.abs.gov.au/ausstats/abs@.nsf/Latestproducts/6523.0Main\%20Features22011-

12 opendocument $\&$ tabname $=$ Summary $\&$ prodno $=6523.0 \&$ issue $=2011-12 \&$ num $=\& v i e w=$. 
- The share of disposable income after taxes and welfare payments going to the top 1 per cent was around the same level in 1987/88, 1996, 2001 and 2009 (Kaplan and Rauh 2013).

- Data from the Congressional Budget Office show that from 1980 to 2010, incomes for the poorest fifth of Americans rose by 44 per cent in real terms before tax, or 53 per cent after tax (Samuelson 2014) - this is significantly greater than the change in Piketty's data.

- Household income inequality after tax (measured by the Gini coefficient) did not increase from 1986 to 2010; this result is in a report otherwise raising concerns with inequality (Lorenzetti 2014).

- The data from estate taxes show no increase in wealth inequality over the past 30 years, similar to results from surveys by the US Federal Reserve (Kopczuk and Schrager 2014).

- The latest data show there has been no increase in the share of wealth owned by the rich, outside the top 0.1 per cent, since 1960 (Saez and Zucman 2014: 3). Piketty himself indicates this data set is more up to date and reliable than the data in Capital (Piketty 2014b). Even the increase for the top 0.1 per cent has been called into question (Reynolds 2014).

For Australia:

- Incomes at the lowest end grew at a strong rate from $1988 / 89$ to $2009 / 10$ (Greenville, Pobke and Rogers 2013: 62).

- Between 2008 and 2013, the share of wealth held by the richest 1 per cent of Australian households fell (Main 2014), and median wealth grew faster than average wealth (Creighton 2014) from 2002 to 2010.

Data for other countries:

- The share of UK income going to labour is largely the same now as it was 40 years ago, so there has been no substantial increase in the share of income going to returns on wealth (Heath 2014).

- The concentration of wealth among the elite in France, Britain and Sweden remains far below what it was in the 19th century; while in the US the income shares of the top groups have been much more stable, although the data are probably less reliable (King 2014). See also Galbraith (2014) and Jones (2014).

It should be noted that there are other studies showing that there has been an increase in inequality (as argued by Summers 2014, McArdle 2014, and Rogoff 2014). To the extent that these other studies are based on tax data, the criticisms raised earlier can also be made. Results from surveys have fewer methodological issues; but, as Piketty has noted, these surveys have only existed for a short time and may not correctly identify top incomes. 


\section{Ignoring general improvements in wellbeing}

Capital also diminishes the clear achievement of recent decades in cutting poverty. The book emphasises the growth in inequality in developing countries (see, for example, Figure 9.9) and plays down the successes in lifting hundreds of millions of people out of extreme poverty, particularly in China (see Cassidy 2014). But it should be hard to see China's economic transformation as anything other than a success. The World Bank (2014) indicates that 'Since 1990, the percentage of the world's population living in extreme poverty, defined as living on less than $\$ 1.25$ per day, has dropped from $36 \%$ in 1990 to $18 \%$ in 2010.' And as noted above, there has been strong growth in the income of the poor in the US (Samuelson 2014) and in Australia (Greenville, Pobke and Rogers 2013).

\section{Piketty's supposed causes of changes in inequality}

After detailing (on questionable foundations) an increase in inequality, Capital then goes on to explore potential reasons for this increase. Many of these arguments are flawed.

\section{Rate of return on wealth}

Capital argues that the rate of return on wealth is on average greater than the economic growth rate. Piketty argues that this is a 'contradiction' (p. 423 and p. 571). This is misleading for those who are not acquainted with Marxist rhetoric - or perhaps he doesn't understand what contradiction means (something that is illogical or inconsistent), or maybe there was an error made in translation. Here he is probably trying to mimic Marx's argument that there are contradictions at the core of capitalism (p. 228).

While it is true that the rate of return on wealth is greater than the economic growth rate over the long run, there are significant periods of time where it hasn't held.

As Piketty himself notes, the value of total wealth fell dramatically during the global financial crisis (GFC), the Great Depression, and the Second World War in Europe; obviously the rate of return would have been strongly negative in those periods. If industrial capitalism has lasted for 180 years, then this relationship has failed to work for a full third of its lifespan, a significant defect in Piketty's theory (Kunkel 2014). 
There is an obvious reason for the (average) return to wealth to be greater than the rate of economic growth - this is to compensate for the risk that returns could be lower. Savers require a risk premium to compensate for uncertainty (King 2014). It is also necessary for there to be a risk premium for saving and investment to occur (McArdle 2014) and for this investment to be efficient over time, even in a communist country (King 2014, Homburg 2014). Note, however, a clear implication of Piketty's argument is that he dislikes investment (discussed below). Piketty himself admits that the returns on capital in practice are extremely volatile (p. 466, 488) and acknowledges the need for a risk premium in passing (p. 54) but ignores this elsewhere, and erroneously attributes the risk premium entirely to a 'time preference' in favour of the present (p. 359).

\section{Growth and persistence in wealth over time}

This sub-section examines the arguments put forward in Capital for the causes of changes in wealth and their persistence over time.

\section{Causes of growth in wealth}

Capital argues that that a high return to wealth drives future increases in wealth.

However, Piketty's own data show that high returns on wealth in the past haven't led to growth in wealth accumulation. The return on wealth greatly exceeded economic growth in Britain, France, the US and Canada in the 18th and 19th centuries, but the ratio of wealth to output stayed relatively stable (Homburg 2014 and Crook 2014).

In addition, Piketty's data show that most of the recent increase in wealth in developed countries comes from land and housing (p. 116-7). Rognlie (2014) argues that housing accounts for about 80 per cent of the increase in wealth, and about 100 per cent of the increase in income from wealth, in eight developed countries (including Australia, the US and the UK) over the period 1970 to 2010. See also Bonnet et al. (2014).

The problem that housing causes for Piketty is that it completely disrupts his argument that high returns to wealth drive savings which in turn drive future wealth. Most of the increase in land and housing is due to capital gains of existing land, not due to saving/investment in new houses and renovation. ${ }^{5}$ Piketty argues the opposite (p. 198), but this argument is easily rebutted by evidence. The definitive source for Australia, the national capital accounts, show that between 1989 and 2013, the value of all land in Australia (excluding improvements such as housing) grew by 482 per cent, and contributed 44.7 percentage points to

5 Technically, capital gains on land should be counted as income in the year the gain occurs, and counted as saving to the extent the land is not sold. But as noted earlier, this is not how Piketty's data work. 
the increase in the net worth of Australia as a whole, while the increased value of houses themselves contributed only 19 percentage points. ${ }^{6}$ Homburg (2014) provides similar results for France.

This error in Piketty's analysis means that little of the recent increase in wealth is caused by high rates of return on wealth (as Piketty measures it), ${ }^{7}$ or from executive salaries. Instead, the growth is due to planning laws (Rognlie 2014; Glaeser, Gyourko and Saks 2005; and Quigley and Raphael 2005) and any resultant 'problems' caused by increasing wealth are best addressed by fixing those regulations.

\section{Inheritances and the persistence of wealth}

Capital argues that inheritances play a major role in enabling the persistence of wealth across generations (pp. 400ff) and inheritances have more influence on the evolution of wealth than saving (p. 377). The role of inheritance declined as mortality rates fell over the past century, but Piketty argues that transfers of wealth may play a larger role in the future. as gifts before death become more prevalent and the wealth of the elderly increases (pp. 392-4).

However, there are important reasons to question the importance of inheritances. In particular, technological change has seen many fortunes appear and disappear.

Piketty argues that the data from the Forbes list of the richest 400 Americans shows large growth in the wealth of the richest Americans (pp. 432-6). However, Piketty measures the total value of the wealth, rather than the persistence of the names on the list. The total value can grow when there are many new entrants to the list, with those already on the list losing funds. In fact, less than one-tenth of the 1982 list was still on the list in 2012, even though most of the members of the 1982 list would have qualified for the 2012 list if they had accumulated wealth at a rate of only 4 per cent (Summers 2014). From 1992 to 2009, 73 per cent of the individuals who appeared on the list of the top 400 tax returns in the US did so for only one year (Epstein and Boudreaux 2014).

Furthermore, the proportion of the Forbes 400 list who are the first generation in their family to run their businesses was 40 per cent in 1982 and rose considerably to 69 per cent in 2011, while the share of those belonging to fourth-, fifth-, and sixth-generation inherited wealth has virtually disappeared (Kaplan and Rauh 2013). The share of the Forbes 400 that grew up wealthy has fallen from 60 per cent in 1982 to 32 per cent today, and the biggest winners on this list are

6 Source: ABS Australian System of National Accounts, 2012-13, Cat No 5204, table 10.

7 Increasing house values will show up in Piketty's data as returns on wealth when the property is sold, but the sale of homes often occurs significantly after the house price has gone up. Piketty also does not include the imputed rents on owner-occupied housing in his measure of income, further distorting his measures of returns on housing wealth. 
typically entrepreneurs, while the biggest losers are often heirs (McBride 2014). Instead, one study finds that 'the typical millionaire is not someone who was born into wealth but rather is someone who has worked hard and lived frugally' (Mankiw 2014).

Rather than wealth persisting, it is often diluted over time when left to multiple heirs and by divorce, consumption, taxes, giving, poor investment decisions or due to market downturns (noting the riskiness of wealth discussed earlier) - see Kopczuk and Schrager (2014) and Posner and Weyl (2014).

\section{Executive salaries}

Capital also blames increased income inequality, mainly in the US, on executive salaries.

Piketty argues that many top managers are able to have significant influence over their own pay (p. 510) regardless of company profitability or managers' productivity (p. 24, p. 334). Piketty argues recent cuts in top marginal tax rates have increased the incentive for executives to push for increases in their pay (p. 509) and there has been a breakdown in social norms that had previously kept a lid on executive salaries (p. 332).

The most fundamental problem with Piketty's argument is that he is effectively arguing that shareholders and boards of directors are making systematic mistakes with their own money. Every dollar that goes to a CEO is a dollar less in profits to shareholders. While corporate governance at many firms is imperfect, it is hard to see how thousands of different companies could independently make the same mistake over and over again, particularly where there are large competitive pressures and intense markets for corporate control. Furthermore, the degree of this 'mistake' is increasing over time as executive salaries increase. As Baker (2014) argues: 'Is it a law of capitalism that shareholders will forever throw money in the toilet by giving unearned bonanzas to CEOs?'

Piketty argues the pay of executives is 'largely arbitrary' (p. 332), but the fact that he can't explain their levels or growth doesn't mean that they are wrong.

\section{Executive salaries - the evidence}

Perhaps unsurprising given Piketty's record so far, his argument that poor decisions by companies are leading to excessive salaries doesn't fit with the evidence.

Corporate governance: there is no evidence that there has been a substantial worsening in corporate governance in the economies experiencing a large increase in executive salaries (Lindsey 2014). Executive pay was lower in the early part 
of the 20th century, when corporate governance was weaker (Frydman and Saks 2010). Recent US legislative changes require shareholder votes on executive compensation; Conyon (2014) finds these votes are overwhelmingly positive. He also finds that the committees that set executive pay have become increasingly independent over time; there is little correlation between the independence of these committees and executive pay and little evidence that performance pay is weaker where committees are less independent.

Private companies: the corporate governance issues of concern to Piketty would be smaller at closely held corporations because they have a reduced principalagent problem between shareholders and boards. However, the pay of CEOs of closely held firms has grown faster than the pay in public companies over recent decades (Kaplan 2013; Cronqvist and Fahlenbrach 2013; Summers 2014; and Bakija, Cole, and Heim 2012). Piketty's research is based on public companies (Manzi 2014) and so misses this distinction.

Social norms: the evidence doesn't support the argument that executive pay has increased because of the decline in social norms that previously discouraged high pay - the pay amongst those who are subject to less disclosure (and arguably less subject to social norms) has increased as well (Kaplan and Rauh 2013; and Bakija, Cole and Heim 2012).

Salaries of other groups: there has been a significant increase in top nonexecutive salaries, including top lawyers and surgeons, hedge fund managers, venture capitalists, and media and sports stars (Lindsey 2014; Kaplan and Rauh 2013). These other increases can't be due to corporate governance; it is much more likely that a common factor has driven all these changes. Manzi (2014) also disputes Piketty's argument (p. 302) that most of the highest incomes are from company executives.

Other potential causes: Piketty too easily dismisses other possible causes of growth in executive salaries. One potential cause is increased size of businesses: one study fully attributes the increase in US executive pay from 1980 to 2003 to the increase in the value of large companies during that period (Gabaix and Landier 2008), and a similar reason could apply to the other highly paid groups. Piketty dismisses this study because this explanation doesn't apply outside the US (footnote 47 to Chapter 14), but Piketty had earlier described the US as the land of 'meritocratic extremism' (Manzi 2014). More substantial CEO wage growth in the US could be because the most productive technologies have been implemented more in the US than elsewhere and the highest paid professionals may have relocated to the US (Kaplan and Rauh 2013). In addition, Gabaix, Landier and Sauvagnat (2014) update the 2008 study and show that CEO pay fairly closely followed firm size downwards during the GFC and upwards since then. 
1. Link with performance: there actually is a close connection between firm performance and salaries, contrary to Piketty's argument. The results in Gabaix, Landier and Sauvagnat (2014) support this. In addition, Kaplan (2013) argues that poor-performing CEOs are much more likely to lose their jobs, with the increased pay likely to reflect the increased risk faced by CEOs.

2. Tax reductions: Piketty cites research arguing that reductions in tax have led to increased executive pay (p. 511), but Manzi (2014) raises substantial concerns with the methodology of this work, as well as many other problems with Piketty's arguments.

\section{Growth in wages and non-executive salaries}

Piketty notes that a reasonable explanation for changes in wages is that technological change has increased the demand for skilled workers, driving up their wages, while the wages of the less skilled fall behind if their skills do not advance sufficiently fast (p. 305). He also argues that wage-setting institutions have a significant impact on wages at the lower end (pp. 307-10). These explanations would be supported by many economists.

However, Capital doesn't put significant weight on the impact of globalisation, which has meant a huge increase in the global labour supply from Asia, weakening competing wages (generally lower paying jobs) - see Elsby et al. (2013), Cassidy (2014) and Ezrati (2014). Wages have also been depressed by substantial (illegal) immigration of low-skilled workers to some countries, particularly the US - a factor that has not affected Australia (Taylor 2014). Piketty accepts that immigration can help poorer workers become more wealthy (p. 538) but does not acknowledge that low-skilled immigration can depress wages at the bottom end in the destination country.

\section{Does inequality matter?}

Capital argues that the forecast increases in inequality are disturbing (p. 421), potentially terrifying (p. 571) and threatening to democracy (pp. 421-2, p. 571). The book also says that wealth, beyond an unspecified level, is indecent and economically useless (p. 473) or even harmful (p. 513), having no use in promoting growth (p. 572) and income on this wealth is an affront to common sense (p. 423). Piketty even praises what he considers to be deliberate policy choices to cut the value of capital in the 1950s and '60s in Europe (p. 149).

Before examining the problems allegedly caused by inequality, it is important to make some general comments on Piketty's dislike of wealth. 


\section{Piketty implies that investment is bad}

Piketty states that the driver of wealth is savings and investment rather than an increase in the value of existing wealth (p. 198). Given his dislike for accumulation of capital (wealth) noted above, Piketty is actually criticising saving and investment. While Piketty doesn't say this explicitly, it is a natural implication of what he is saying.

Saving and investment are bad??? This is an absurd implication for an economist to make. It goes against voluminous evidence showing the benefits of investment. This evidence almost doesn't need re-stating. But to give one example from the Australian Treasury: Gali and Taplin (2012) found a reduction of capital inflow and investment to Australia of 1 per cent of GDP 'will reduce gross national income by about half a per cent each year in the first decade relative to baseline. Other things being equal, restrictions on capital inflow (including foreign investment) would reduce Australian investment, production and incomes. In turn, this would reduce the wellbeing of Australians.'

Piketty is effectively arguing that 'The capitalist who squanders his fortune is a better friend to labor than the one who lives modestly and reinvests his surplus. In Piketty's view of the world, where inequality is all that counts, capital accumulation is almost a sin in its own right' (Crook 2014). Similar arguments are in McArdle (2014) and Jones (2014).

Importantly, Piketty's implied argument can't be explained away as Piketty criticising the saving and investment of the super-rich alone - he actually is specifically critical of the accumulation of capital by the moderately well off (p. 421) and is pretty lukewarm on the concept of pension plans investing in shares (pp. 488ff).

Piketty has a special disdain for foreign investment (pp. 69-72, p. 121, pp. 458460). He seems to think that foreign investment has no useful function whatsoever and causes significant irritation in the country that receives the investment. He completely fails to explain why on earth many countries go out of their way to attract foreign investment if this investment is without merit. Piketty thinks countries with significant foreign investment are less successful, have an 'almost irrepressible demand for expropriation' and significant investment is 'almost impossible' to sustain without a colonial type of domination (p. 70). He is clearly unaware of Australia's successes with a substantial level of foreign investment. Gali and Taplin (2012), discussed above, show the benefits of foreign investment to Australia. 
Agenda, Volume 21, Number 1, 2014

\section{Specific problems with wealth}

Piketty's reasons for disliking inequality are discussed below.

Expropriation by the rich: it appears that Piketty thinks the most important problem with inequality is that it means that income that would otherwise go to the poor is being captured, distributed to or claimed by the rich (see, for example, pp. 263-4, p. 269), as though the rich had seized the income from the poor. On page 297, he extraordinarily talks about the 'transfer' of income from the poor to the rich (similar arguments are on p. 378, pp. 416-7, and p. 439).

The main problem with this rhetoric is that it is implying that there aren't any benefits (gains) from domestic or international trade - Piketty is effectively suggesting that any trade involves the distribution of value rather than the creation of value. When one party to a transaction gains, this implies that the other party must be losing. This is an implication that all economists should strongly reject as being completely contrary to the way a market economy works, most obviously because if there aren't gains from trade, then it should be asked why any trade occurs at all.

This 'zero-sum' rhetoric also completely ignores the large improvements in wellbeing the poor have had over recent decades (as discussed earlier), particularly when tax and income support is included. Everyone, including the poor, has had increases in disposable income, so nobody has 'lost' as Piketty implies.

Undemocratic: Piketty's argument that inequality is threatening to democracy could be based on the rich using their considerable resources to influence politics. But there are rich who support leftwing causes - think Warren Buffett, George Soros, some internet entrepreneurs and much of Hollywood; a specific example is in Hanauer (2014). Furthermore, the supposed growth in incomes of the super-rich in the US hasn't prevented the election of Barack Obama who has proposed many left-friendly policies (Mankiw 2014). And to the extent that the government is being 'bought', the best solution is to reduce the scope of government - a solution Piketty and his fellow travellers are unlikely to support.

Government preferment: Piketty is on firmer ground to the extent he is criticising wealth that has been obtained by government preferment and rent seeking. However, Piketty basically argues that much of what is paid to the rich is unfair in some way or another even if there is no obvious rent seeking (pp. 422-3). In any case, rent seeking is not an exclusive purview of the very rich. 'In New South Wales the ICAC has shown that wealth is neither a necessary nor sufficient condition to wield corrupt influence. It wasn't inherited riches that gave us Eddie Obeid.' (Berg 2014). And if rent seeking is driving inequality, then the best response is to address this problem directly (Mankiw 2013). 


\section{Piketty's solution - taxes on capital income and wealth}

Piketty proposes that the 'problems' caused by inequality should be addressed by large increases in taxes on capital income and wealth.

\section{Impact on the economy}

Piketty seems completely oblivious to the adverse effects of taxes on capital, arguing that punitive taxes would not reduce growth rates (p. 513). As Rogoff (2014) states: 'I don't understand why he [Piketty] assumes that an 80 per cent [tax] rate would not cause significant distortions, especially as this assumption contradicts a large body of work by the Nobel laureates Thomas Sargent and Edward Prescott.' Heath (2014) argues that 'eating capital is the best way to impoverish a nation, reduce productivity growth and keep wages down'.

Notably, the Henry Tax Review in Australia in 2009 and the Mirrlees Tax Review in the UK in 2011, involving those with much more tax expertise and knowledge than Piketty, both recommended that taxes on saving and investment should be lowered, not raised (Henry et al. 2009; Institute for Fiscal Studies and Mirrlees 2011). The Mirrlees Review found that a tax on wealth is 'not appealing ... [it has] very serious practical difficulties ... [and] practical experience has not been encouraging' and indicated there were persuasive arguments against such a tax (p. 347).

\section{Other problems with tax on wealth}

Implementation: there are obvious implementation problems with higher taxes on wealth - if they are not internationally coordinated, then the rich will simply move their wealth into low-tax countries. However, the possibility of implementing a globally agreed wealth tax is minimal, as Piketty himself acknowledges (p. 515, 529) but he then appears to assume this issue away. Commentators drawing attention to the difficulties of implementation include Joel Slemrod, a prominent tax economist at the University of Michigan (cited in Coy 2014); Larry Summers (2014), who was Bill Clinton's Secretary of the Treasury; James Galbraith (2014), who is otherwise very sympathetic to Piketty's views; and Kenneth Rogoff (cited in McArdle 2014). Summers (2014) also notes various implementation problems such as valuing closely held businesses and dealing with jurisdictions that deliberately undervalue assets to attract investment. 
Fairness: Piketty's wealth tax will apply to wealth obtained both 'fairly' and 'unfairly'. However, it is quite debatable whether there are significant incomes and wealth that have been 'unfairly' acquired. In particular, Piketty's evidence that executives are being overpaid by compliant shareholders is pretty flimsy. And any unfairness would be best addressed directly.

Common tax rate: Piketty argues that all wealth should be taxed at the same rate (p. 531). He completely ignores a core principle in the design of optimal taxesthat tax rates should be lower on more mobile assets (e.g. financial wealth) and higher on less mobile assets (e.g. land). His ignorance is particularly on display when he argues that it is hard to think of an economic principle that would tax land at a much higher rate than financial assets (p. 528).

Confiscation: Piketty's proposed tax rates are punitive. His option for a 10 per cent tax rate on wealth (p. 530) is equivalent to a 250 per cent tax on capital income (Homburg 2014), assuming as Piketty does a 4 per cent return on capital. This is obviously expropriation of wealth/income, an outcome that he elsewhere argues against (p. 505).

\section{Other solutions}

Piketty discusses some other solutions to the alleged problems caused by inequality.

Broader capital ownership: if there are higher returns to capital and this is driving inequality, then this could obviously be addressed by wider ownership of capital. Pension plans could invest more in shares, which enables a wider distribution of the benefits of a higher return to capital (Heath 2014; Williamson 2014; Edsall 2014; and Summers 2014). This concept is already followed by the Australian superannuation system. There could also be greater use of profit participation and employee share schemes (Kruse, Freemen and Blasi 2010).

Perhaps unsurprisingly, Piketty is unenthusiastic about these ideas, even though these would partly address his concerns. He argues that the owners of a moderate amount of wealth ('petits rentiers') are a very large demographic group which will get larger, grow wealthier and pass on assets to the next generation and this presents 'a fairly disturbing form of inequality' (p. 421). In addition, his support for pension plans investing in shares is pretty lukewarm (pp. 488ff). The left more broadly is fairly hostile to profit participation and (for the US) private pension accounts. 
Piketty does not raise nationalisation of capital as a solution - probably because he recognises the manifold problems when this was implemented en masse in communist countries (p. 138).

Education: Piketty himself considers that knowledge and skill diffusion are the key to reducing inequality (p. 21, 306-7) but is also fairly lukewarm about education as a solution (pp. 483-7). Improving educational productivity would increase economic growth and address low pay (poverty), which should be more of a focus for policymakers.

Minimum wages: Capital argues that minimum wages and 'rigid wage schedules' can reduce wage inequality and are part of the reason for the comparative evolution of wage inequality in the US and France (p. 308). Piketty makes some misguided claims in this area. He argues that it can be in everyone's interest for workers to have their monthly income guaranteed, and workers may invest less in firm-specific knowledge if they don't know their wage in advance (pp. 311-2). But both of these issues can be addressed directly through negotiation between workers and employers; and imposing this through 'rigid wage schedules' restricts the use of performance pay and profit participation which can increase wages, increase productivity and reduce layoffs in recessions (Kruse 1993; Estrin et al. 1997; and Kruse, Freemen and Blasi 2010). Piketty also argues that allowing employers to set wages can be arbitrary (p. 311), but he presents no evidence that wage setting by an industrial tribunal is less arbitrary. Notably Piketty argues that significant minimum wage increases shouldn't occur when the minima are already at high levels, such as in France, because unemployment will result (p. 313) - and the minimum wage in Australia is higher than that in France.

\section{Conclusion}

The argument by Piketty and others that there is growing inequality and this is causing damage is not new. But regardless of who is running this argument, it is significantly flawed. The poor have definitely improved their situation, especially if taxes and income support are included, in many countries in the developing world and the US. A focus on inequality to the exclusion of poverty glosses over the large successes over recent decades. It paints a false picture of decline when large improvements have occurred.

To the extent there have been increases in executive wages, this has probably been driven by technology and globalisation, not by poor corporate governance. And the returns to wealth being (relatively) high should be expected given the riskiness of owning wealth, and is actually necessary to ensure that investment occurs. 
Piketty's (implied) argument that investment is bad should be dismissed out of hand, as should his argument that high taxes are required on wealth. Instead, the problems generated by 'unfairly' acquired wealth should be addressed by removing rents. Policymakers should consider broadening the ownership of capital and assisting those who are in genuine need, and reject proposals that pander to envy.

\section{References}

Armour, P., Burkhauser, R.V. and Larrimore, J. 2013, 'Levels and Trends in United States Income and Its Distribution A Crosswalk from Market Income Towards a Comprehensive Haig-Simons Income Approach', NBER Working Paper 19110.

Baker, D. 2014, 'Capital in the 21st Century: Still Mired in the 19th' Huffington Post Blog, 9 March, available at: www.huffingtonpost.com/dean-baker/ capital-in-the-twenty-fir_b_4932184.html.

Berg, C. 2014, 'We should fear slow growth, not inequality'. The Drum (ABC). Available at: www.abc.net.au/news/2014-04-29/berg-we-should-fear-slowgrowth-not-inequality/5417366.

Bonnet, O, Bono, P-H., Chapelle, G. and Wasmer, E. 2014, 'Does Housing Capital Contribute to Inequality? A Comment on Thomas Piketty's Capital in the 21st Century'. Sciences Po publications. Available at: http://ideas.repec. org/p/spo/wpmain/infohdl2441-30nstiku669glbr66l6n7mc2oq.html.

Burkhauser, R.V. and Larrimore, J. 2014, 'Correspondence - The One Percent', Journal of Economic Perspectives 28(1): 243-8.

Cassidy, J. 2014, 'Forces of Divergence', The New Yorker, 31 March. Available at: www.newyorker.com/arts/critics/books/2014/03/31/140331crbo_books_ cassidy.

Conyon, M. 2014, 'Executive Compensation and Board Governance in US Firms', Economic Journal 124(574): F60-F89.

Coy, P. 2014, 'An Immodest Proposal: A Global Tax on the Superrich', BusinessWeek, 10 April. Available at: www.businessweek.com/printer/ articles/194541-an-immodest-proposal-a-global-tax-on-the-superrich.

Creighton, A. 2014, 'Inheritance wins out over saving', The Australian, 13 Jun 2014. Available at: www.theaustralian.com.au/business/opinion/inheritancewins-out-over-saving/story-fnc2jivw-1226952476159. 
Crook, C. 2014, 'The Most Important Book Ever Is All Wrong', BloombergView. Available at: www.bloombergview.com/articles/2014-04-20/the-mostimportant-book-ever-is-all-wrong.

Cross, P. 2014, 'A Failure on Several Counts: Thomas Piketty's Capital in the Twenty-First Century', Fraser Institute Research Study. Available at: www. fraserinstitute.org/research-news/display.aspx?id=21774.

Edsall, T.B. 2014, 'Capitalism vs. Democracy' The New York Times. Available at: www.nytimes.com/2014/01/29/opinion/capitalism-vs-democracy.html.

Elsby, M.W.L., Hobijn, B. and Şahin, A. 2013, 'The Decline of the U.S. Labor Share', Brookings Papers on Economic Activity 2013(2): 1-63.

Epstein, G. and Boudreaux, D. J. 2014, 'Piketty: A Wealth of Misconceptions', Barrons. Available at: http://online.barrons.com/news/articles/SB500014240 53111903301904579564170989136720.

Estrin, S., Pérotin, V., Robinson, A. and Wilson, N. 1997, 'Profit-Sharing in OECD Countries a Review and Some Evidence', Business Strategy Review 8(4): $27-32$.

Ezrati, M. 2014, 'What Prof. Piketty Missed', Huffington Post, 22 July. Available at: www.huffingtonpost.com/milton-ezrati/what-prof-pikettymissed_b_5606299.html.

Gabaix, X. and Landier, A. 2008, 'Why has CEO Pay Increased So Much?' Quarterly Journal of Economics 123(1): 49-100.

Gabaix, X., Landier, A. and Sauvagnat, J. 2014, 'CEO Pay and Firm Size: An Update After the Crisis' Economic Journal 124(574): F40-F59.

Gali, J. and Taplin, B. 2012, 'The Macroeconomic Effects Of Lower Capital Inflow', Economic Roundup 3.

Galbraith, J. K. 2014, 'Kapital for the Twenty-First Century?' Dissent Magazine, Spring, available at: www.dissentmagazine.org/article/kapital-for-thetwenty-first-century.

Giles, C. and Giugliano, G. 2014, 'Thomas Piketty's exhaustive inequality data turn out to be flawed', Financial Times, 23 May. Available at: www.ft.com/ intl/cms/s/0/c9cela54-e281-1le3-89fd-00144feabdc0.html.

Greenville, J., Pobke, C. and Rogers. N. 2013, Trends in the Distribution of Income in Australia, Productivity Commission Staff Working Paper 
Hanauer, N. 2014, 'The Pitchforks Are Coming ... For Us Plutocrats'. POLITICO Magazine, July/August 2014. Available at: www.politico.com/magazine/ story/2014/06/the-pitchforks-are-coming-for-us-plutocrats-108014.html.

Heath, Allister (2014) 'Thomas Piketty's bestselling post-crisis manifesto is horrendously flawed' The Telegraph, 29 April, London. Available at: http:// www.telegraph.co.uk/finance/economics/10796532/Thomas-Pikettysbestselling-post-crisis-manifesto-is-horrendously-flawed.html.

Henry, K., Harmer, J., Piggott, J., Ridout, H. and Smith, G. 2009, Australia's Future Tax System.

Homburg, S. 2014, 'Critical Remarks on Piketty's "Capital in the Twenty-first Century"', Leibniz Universität Hannover, Wirtschaftswissenschaftliche Fakultät Discussion Paper No. 530. Available at: http://ideas.repec.org/p/ han/dpaper/dp-530.html.

Institute for Fiscal Studies and Mirrlees, J. (eds) 2011, Tax by design-the Mirrlees Review, Oxford University Press.

Jones, G. 2014, 'Living with Inequality', reason.com, 26 April, available at: http://reason.com/archives/2014/04/26/living-with-inequality.

Kaplan, S. 2013 'The Real Story Behind Executive Pay', Foreign Affairs. Available at: www.foreignaffairs.com/articles/139101/steven-n-kaplan/the-real-storybehind-executive-pay.

Kaplan, S., and Rauh, J. 2013, 'It's the Market: The Broad-Based Rise in the Return to Top Talent', Journal of Economic Perspectives 27(3): 35-56.

King, M. 2014, 'Capital in the Twenty-First Century by Thomas Piketty, review'. The Telegraph, 10 May 2014, London. Available at: www.telegraph.co.uk/ culture/books/bookreviews/10816161/Capital-in-the-Twenty-First-Centuryby-Thomas-Piketty-review.html.

Kopczuk, W. and Schrager, A. 2014, 'The Inequality Illusion - why a wealth tax won't work' Foreign Affairs, 15 May. Available at: www.foreignaffairs.com/ articles/141431/wojciech-kopczuk-and-allison-schrager/the-inequalityillusion.

Kotlikoff, L. 2014, 'Will the rich always get richer? Making Sen\$e'. PBS NewsHour. Available at: www.pbs.org/newshour/making-sense/will-richalways-get-richer/.

Krugman, P. 2014, 'Why We're in a New Gilded Age' New York Review of Books, 8 May. 
Kruse, D. 1993, 'Does Profit Sharing Affect Productivity?' NBER Working Paper No. 4542.

Kruse, D., Freeman, R. and Blasi, J. 2010, Shared Capitalism at Work: Employee Ownership, Profit and Gain Sharing, and Broad-Based Stock Options, University Press.

Kunkel, B. 2014, 'Paupers and Richlings' London Review of Books 36(13).

Lakner, C. and Milanovic, B. 2013, 'Global Income Distribution From the Fall of the Berlin Wall to the Great Recession', World Bank Policy Research Working Paper 6719.

Lindsey, B. 2014, 'What Thomas Piketty Gets Wrong About Capitalism', Reason. com, 23 May, available at: http://reason.com/archives/2014/05/23/whatthomas-piketty-gets-wrong-about-cap.

Lorenzetti, L. 2014, 'Income inequality is holding back the economy, says S\&P', Fortune, 5 August, available at: http://fortune.com/2014/08/05/incomeinequality-is-holding-back-the-economy-says-sp/.

Main, A. 2014, 'Shares make new millionaires', The Australian, 12 June 2014. Available at: www.theaustralian.com.au/business/wealth/shares-make-newmillionaires/story-e6frgac6-1226951180385.

Mankiw, N.G. 2013, 'Defending the One Percent', Journal of Economic Perspectives 27(3): 21-34.

- 2014, 'Correspondence - The One Percent', Journal of Economic Perspectives 28(1): 243-8.

Manzi, J. 2014, 'Piketty's Can Opener', National Review Online, 7 July. Available at: www.nationalreview.com/corner/382084/pikettys-can-opener-jimmanzi.

McArdle, M. 2014, 'Piketty's Capital: An Economist's Inequality Ideas Are All the Rage', BusinessWeek: global_economics. Available at: www.businessweek. com/printer/articles/203908-pikettys-capital-an-economists-inequalityideas-are-all-the-rage.

McBride, W. 2014, 'Thomas Piketty's False Depiction of Wealth in America', Tax Foundation Special Report 223.

Milanovic, B. 2013, "The return of "patrimonial capitalism": review of Thomas Piketty's Capital in the 21st century'. Available at: http://mpra.ub.unimuenchen.de/52384/. 
Mount, F. 2014, 'Piketty's decaff Marxism would be just oppressive and intrusive as the old variety', The Spectator, 24 May. Available at: http:// specc.ie/1lTbZZi.

Murdock, D. 2014, 'Thatcher: "They Would Rather Have the Poor Poorer"', National Review Online. Available at: www.nationalreview.com/ corner/344974/thatcher-they-would-rather-have-poor-poorer-deroymurdock.

Neumark, D. and Muz, J. 2014, "The "Business Climate" and Economic Inequality', NBER Working Paper No. 20260.

Piketty, T. (trans. Arthur Goldhammer) 2014a, Capital in the Twenty First Century, Belknap Press.

— 2014b, 'My Response to the Financial Times', Huffington Post. Available at: $\quad$ www.huffingtonpost.com/thomas-piketty/response-to-financialtimes_b_5412853.html.

Posner, E. and Weyl, G. 2014, 'Thomas Piketty Is Wrong: America Will Never Look Like a Jane Austen Novel', The New Republic, 31 July. Available at: www. newrepublic.com/article/118925/pikettys-capital-theory-misunderstandsinherited-wealth-today.

Reynolds, A. 2014, 'Why Piketty's Wealth Data Are Worthless', Wall Street Journal, 9 July. Available at: http://online.wsj.com/articles/alan-reynoldswhy-pikettys-wealth-data-are-worthless-1404945590.

Rognlie, M. 2014, 'A note on Piketty and diminishing returns to capital', mimeo. Available at: www.mit.edu/ mrognlie/piketty_diminishing_returns.pdf.

Rogoff, K. 2014, 'Where Thomas Piketty is right - and so wrong', Australian Financial Review, 13 May 2014. Available at: www.afr.com/p/opinion/ where_thomas_piketty_is_right_and_LPgWBGIVXKLXA0eMoQ1cWJ.

Saez, E. and Zucman, G. 2014, 'The Distribution of US Wealth, Capital Income and Returns since 1913', mimeo. Available at: http:/gabriel-zucman.eu/files/ SaezZucman2014Slides.pdf.

Samuelson, R.J. 2014, 'Myth-making about economic inequality', The Washington Post, 2 February. Available at: www.washingtonpost.com/opinions/robertsamuelson-myth-making-about-economic-inequality/2014/02/02/4cda72ac8a9a-11e3-a5bd-844629433ba3_story.html.

Stanley, T. and Danko, W. 1996, The Millionaire Next Door: Surprising Secrets of America's Wealthy, Longstreet Press. 
Stiglitz, J. 2013, The Price of Inequality: How Today's Divided Society Endangers Our Future, W.W. Norton \& Company.

Summers, L. 2014, 'The Inequality Puzzle', Democracy Journal. Available at: www.democracyjournal.org/32/the-inequality-puzzle.php.

Tanner, M. 2014, 'Piketty Gets It Wrong', National Review Online. Available at: www.nationalreview.com/article/376304/piketty-gets-it-wrong-michaeltanner.

Taylor, A. 2014, 'Why Stiglitz is selling us a lemon', Australian Financial Review, 10 July 2014. Available at: www.afr.com/p/opinion/why_stiglitz_is_selling_ us_lemon_Fplt8kvy5Mk4N6j123FlJI.

The Economist 2013, 'Lexington - The American Dream, RIP?', 21 September, Available at: www.economist.com/news/united-states/21586581-economistasks-provocative-questions-about-future-social-mobility-american.

VanderMey, A. 2014, 'Contagion - How America fell in love with a 685page economics treatise', Fortune, 22 August. Available at: http://fortune. com/2014/08/22/contagion-how-america-fell-in-love-with-capital-piketty/.

Voitchovsky, S. 2005, 'Does the Profile of Income Inequality Matter for Economic Growth?', Journal of Economic Growth 10(3): 273-96.

Wilkinson, R. and Pickett, K. 2009, Spirit Level: Why More Equal Societies Almost Always Do Better, Allen Lane.

Winship, S. 2014, 'Whither The Bottom 90 Percent, Thomas Piketty?' Forbes, 17 April. Available at: www.forbes.com/sites/scottwinship/2014/04/17/ whither-the-bottom-90-percent-thomas-piketty/.

Wolff, E.N. and Gittleman, M. 2011, 'Inheritances and the Distribution of Wealth or Whatever Happened to the Great Inheritance Boom? Results from the SCF and PSID', NBER Working Paper 16840.

World Bank 2014, 'Prosperity for All: Ending Extreme Poverty'. Available at: $\quad$ www.worldbank.org/en/news/feature/2014/04/10/prosperity-for-allending-extreme-poverty.

Worstall, T. 2014, 'Contra Piketty Sweden Is More Unequal Than Britain', Forbes, 14 August. Available at: www.forbes.com/sites/timworstall/2014/08/14/ contra-piketty-sweden-is-more-unequal-than-britain/. 
This text taken from Agenda: A Journal of Policy Analysis and Reform Volume 21, Number 1, 2014, published November 2014 by ANU Press, The Australian National University, Canberra, Australia. 